\title{
CYCLODEXTRINS - FIELDS OF APPLICATION. PART I
}

\author{
Gheorghe Duca ${ }^{\mathrm{a}}$, Veaceslav Boldescu $\mathrm{b}^{\mathrm{k}}$ \\ ${ }^{a}$ Academy of Sciences of Moldova, Stefan cel Mare, 1, Chisinau, Republic of Moldova, \\ ${ }^{b}$ Department of Industrial and Ecological Chemistry, State University of Moldova, 60, Mateevici str., MD 2009, Chisinau, \\ Republic of Moldova, * tel. (+373 79) 454062, fax (+373 22) 244248, e-mail: sboldescu@yahoo.com
}

\begin{abstract}
This review is dedicated to different fields of use of cyclodextrins, a family of three cyclic natural oligosaccharides and their derivatives. The first part of the review gives a brief description of the main and the most recent developed applications of cyclodextrins in food, cosmetic industry, environmental protection technologies and agriculture. Different products based on inclusion complexes with cyclodextrins and technologies with different use of cyclodextrins and inclusion complexes are described.
\end{abstract}

Keywords: cyclodextrins, food, cosmetic industry, environmental protection, agriculture

Cyclodextrins are a family of three cyclic natural oligosaccharides and their semi-synthetic derivatives. Naturally occurring $\alpha$-, $\beta$ - and $\gamma$-cyclodextrins have torus-like macro-rings built up from 6,7 and 8 glucopyranose units, respectively. As a consequence of the ${ }^{4} \mathrm{C}_{1}$ conformation of the glucopyranose moieties, all the primary hydroxyl groups are situated on the one edge of the torus, while all the secondary ones are situated on the other. The internal cavity of the cyclodextrins is lined by the hydrogen atoms and the glycosidic oxygen bridges, which produce a high electron density there and lend to it somewhat hydrophobic character.

In an aqueous solution, the cyclodextrin cavity is occupied by water molecules that are energetically unfavored due to polarapolar interactions, and therefore can be readily substituted by any less polar guest-molecule added to the solution. The properties of the included molecule are very often significantly modified and the formed inclusion complexes find wide distribution in different fields of application.

The main reasons why the cyclodextrins are that popular as guests for inclusion of different substances:

- they are produced from a renewable natural material (starch) applying environmental-friendly technologies (enzymatic conversion);

- they are relatively cheap and are produced in amounts of thousands of tones per year;

- they are nontoxic in consumable concentrations and their secondary toxic effects can be easily eliminated by an appropriate chemical modification;

- they are biodegradable and do not pollute the environment.

The main fields of cyclodextrins application are:

1. agriculture;

2. biotechnological applications;

3. chemical and biological analysis;

4. chemical synthesis;

5. cosmetic industry;

6. environmental protection technologies;

7. food industry;

8. pharmaceutical industry;

9. textile industry.
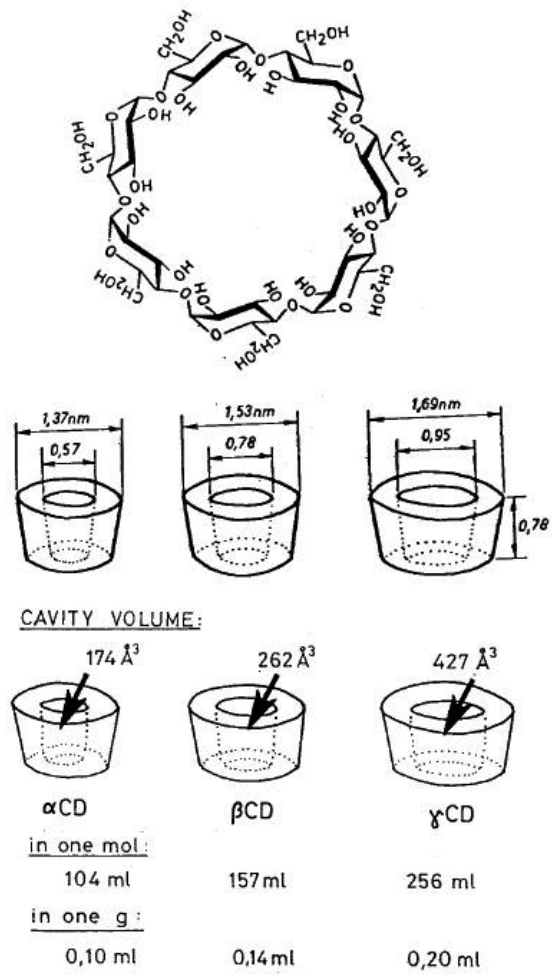

Fig. 1. Forms of natural cyclodextrins

This paper is dedicated to application of cyclodextrins in food and cosmetic industry, environmental protection technologies and agriculture.

\section{Food industry}

Food and cosmetic industries are the largest consumers of cyclodextrins and their derivatives [1]. In the food industry cyclodextrins are employed for the production of a wide variety of goods from alcohol powder to low-cholesterol cheese and milk. 
Cyclodextrins are used to replace:

a) carbohydrates with a high glycemic index such as sugar, starch or starch-derived products to reduce the energy value and glycemic load of the food;

b) fat in table spreads;

c) fermentable fibers, some of which may be less suitable because of their high viscosity, insufficient stability, taste or presence of by-products.

In other cases, cyclodextrins are added to foods in which they doesn't directly replace any particular component but perform a range of technical functions such as:

a) a carrier for natural colors, flavors and vitamins;

b) a stabilizer of oil in water emulsions, a solubilizer of lipids;

c) a flavor and aroma modifier by suppressing undesirable characteristics.

$\gamma$-cyclodextrin was proved to possess the best flavor retention properties among 3 native cyclodextrins [2]. A group of flavor substances are known to be used under the form of inclusion complexes with cyclodextrin: coffee flavor [3], wasabi flavor additive [4], vanillyl alcohol derivatives [5], lemon oil [6]. Color stabilization in food is another widespread application of cyclodextrins [7-9]. Most stabilized are natural colorants like lycopene, quercetine, $\beta$-carotene and others.

The estimated levels of cyclodextrins used as a food ingredient are higher (up to approximately 15\%) than when they are used for a technological function (approximately 1\%).

Cyclodextrins can stabilize emulsions of fats and oils [10], shielding them from oxidation and thus preventing rancidity. They can also be used to debitter citrus juices through removal of bitter components rather than masking them. $[11,12]$

Besides, they can be used in production of powdered products like powdered tea [13], powdered honey [14] or powdered alcohol [15]. Very often cyclodextrins are used for sweeteners stabilization and solubilization: aspartame (1), neotame (2), steviolmonoside (3, R= $\mathbf{\beta G l c})$, steviolbioside ( $\mathbf{3}, \mathbf{R}=\boldsymbol{\beta} \mathbf{G l c}-\boldsymbol{\beta G I c})$ and others. [16-18]<smiles>COC(=O)[C@H](Cc1ccccc1)N(NC(=O)[C@@H]([NH3+])CC(=O)[O-])C(=O)[O-]</smiles>

(1)<smiles>COC(=O)[C@H](Cc1ccccc1)N(N)C(=O)[C@H](CC(=O)O)NCCC(C)(C)C</smiles>

(2)

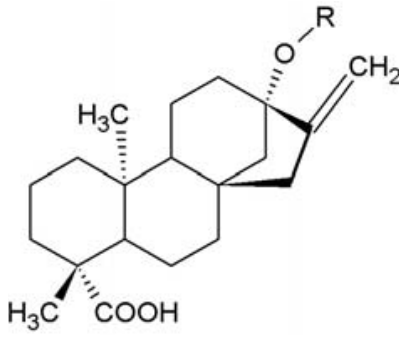

(3)

Fig. 2. Structures of some sweeteners for which cyclodextrin complexes have been developed: aspartame (1),

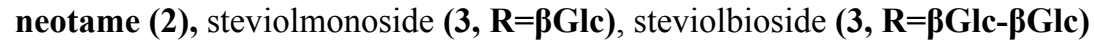

With respect to bioconversions and fermentations, cyclodextrins apparently possess an advantageous combination of properties. First, they enhance solubilization of organic compounds. Second, they reduce toxicity since complexation of organic substrates and/or products may significantly reduce their concentrations. Third, they are biocompatible. Cyclodextrins are known to cause no damage either to free enzymes or to micro-organisms.

A wide range of cyclodextrin technologies are applied to produce healthy food products with different effects:

- reduced cholesterol content: homogenized milk [19], cream [20]; cheddar cheese [21], butter [22], egg yolks [23]

- hypocholesterolemic effect [24]

- reduced glycemic index [25]

- antiallergic effect [26]

Other possible applications of cyclodextrins in food industry are production of gasified products [27], food cleaning products [28]. In the table 1 are presented different food products and cyclodextrin concentrations approved for them. 
$\alpha$ - and $\gamma$-cyclodextrins in foods/levels of use $[29,30]$

\begin{tabular}{|l|c|c|c|c|c|c|}
\hline \multirow{2}{*}{ Food name } & \multicolumn{2}{c|}{$\begin{array}{c}\text { Cyclodextrin } \\
\text { concentration } \\
\text { level, \% }\end{array}$} & $\begin{array}{c}\text { Hydration factor } \\
\text { for } \alpha \mathrm{CD} / \text { dilution } \\
\text { factor for } \gamma \mathrm{CD}\end{array}$ & \multicolumn{2}{c|}{$\begin{array}{c}\text { Level used in modeling, } \\
\text { g/kg }\end{array}$} \\
\cline { 2 - 7 } & $\alpha \mathrm{CD}$ & $\gamma \mathrm{CD}$ & $\alpha \mathrm{CD}$ & $\gamma \mathrm{CD}$ & $\alpha \mathrm{CD}$ & $\gamma \mathrm{CD}$ \\
\hline Baked goods & & 2,0 & & & & 20 \\
\hline Beverage whiteners & 1,0 & 1,0 & & & 10 & 10 \\
\hline Biscuits & 10,0 & 1,0 & & & 100 & 10 \\
\hline Breads & 5,0 & 1,0 & & & 50 & 10 \\
\hline Breakfast foods & & 2,0 & & & & 20 \\
\hline Chewing gum & 10,0 & 1,0 & & & 100 & 10 \\
\hline Dairy desserts & 1,0 & 3,0 & 7,8 & & 1,3 & 30 \\
\hline Dry mixes for beverages & & 1,0 & & 10 & & $* 1,0$ \\
\hline Dry mixes for dressings, gravies and sauces & & 1,0 & & 5 & & $* 2,0$ \\
\hline Dry mixes of soups & & 1,0 & & 20 & & $* 0,5$ \\
\hline $\begin{array}{l}\text { Dry mixes for puddings, desserts, jellies and } \\
\text { fillings }\end{array}$ & & 1,0 & & 6 & & $* 1,7$ \\
\hline Ice cream/ice confection & 2,5 & & & & 25 & \\
\hline Fat based fillings & & 5,0 & & & & 50 \\
\hline Fermented or rennetted milk & 2,5 & & & & 25 & \\
\hline Fruit based fillings & & 3,0 & & & & 30 \\
\hline Instant coffees and teas & 1,0 & 1,0 & 113 & 80 & 0,088 & $* 0,125$ \\
\hline Processed cheese & & 3,0 & & & & 30 \\
\hline Salt & 3,0 & & & & 30 & \\
\hline Savory snacks & 1,0 & 1,0 & & & 10 & 10 \\
\hline Soy beverages & 2,0 & 2,0 & & & 2,0 & 20 \\
\hline Sugar confectionary (compressed) & 15,0 & 1,0 & & & 150 & 10 \\
\hline Oil emulsions (<80\% fat) & 20,0 & & & & 200 & \\
\hline Table spreads & & 20,0 & & & & 200 \\
\hline * in \%
\end{tabular}

* in the 'ready to consume' version of the food

\section{Cosmetic industry}

The cosmetic industry is constantly looking for new and effective products endowed with a satisfactory biological activity and an efficient delivery on the skin, hair and nails. Cyclodextrins, as cosmetic ingredients, are used to solubilize and stabilize sensitive components; stabilize emulsions; improve the absorption of active compounds; stabilize emulsions; reduce or eliminate bad smells of some cosmetic ingredients, and reduce the loss of active component through photodestruction, oxidation, volatilization. Besides, they are used in hygienic products aiming to interact with body secretions (sebum, sweat).

Below are demonstrated different examples of cyclodextrin application in cosmetic products:

1. Use as delivery systems or solubilizers for different cosmetic compounds

- delivery of fragrance materials - linalool (4) and benzyl acetate (5) [31];

- delivery of biologic active compounds - coenzyme Q10 (6) [32], adapalene (7) [33],

- solubilizers for hydrophobic preservatives [34, 35].

2. Improvement of physical and chemical stability:

- protection of active ingredient(s) against oxidation - vitamin F in dermatological preparations [36];

- light-induced reactions - retinol [37], 4-methylbenzylidene camphor [38], ferulic acid (8) [39] photostabilization;

- prevention of degradation, heat-promoted decomposition storage stability [40, 41]

- reduction of loss by volatility, sublimation [42-45]

- stabilization of emulsions - as emulsifiers [46]

3. Improvement of sensoric properties:

- elimination or reduction of undesirable tastes and odors, microbiological contamination - use in deodorants [47];

- modifying hair properties - smoothing hair combability [48]

4. Reduction of penetration of sunscreen agents in skin layers [49, 50]

5. Production of cosmetic preparations for the removal of sebum and seborrhea treatment [51] 
<smiles>C=CC(C)(O)CCC=C(C)O</smiles>

(4)<smiles>CC(=O)OCc1ccccc1</smiles>

(5)<smiles>COC1=C(OC)C(=O)C(CC=C(C)CC2CC2)=C(C)C1=O</smiles>

(6)<smiles>COc1ccc(-c2ccc3cc(C(=O)O)ccc3c2)cc1C12CC3CC(CC(C3)C1)C2</smiles>

(7)<smiles>COc1cc(/C=C/C(=O)O)ccc1O</smiles>

(8)

Fig. 3. Structures of some cosmetic ingredients for which cyclodextrin complexes have been developed: linalool (4), benzyl acetate (5), coenzyme Q10 (6), adapalene (7), ferulic acid (8)

\section{Environmental protection technologies}

Cyclodextrins have been widely studied as for removal of different contaminants from waste gases, wastewater, contaminated soil. Besides, cyclodextrins are used in technologies of reduction of wastes emissions. Several technologies have been developed and approved by pilot scale experiments. Despite the obvious advantages, the environmental application of CDs is still hindered by their price.

\section{Gaseous and volatile pollutants sorption:}

- Sorption of organic solvent vapor from waste gases of chemical industry by CD solution and CD polymers [52-54];

- Sorption of radioactive iodine from the waste gases of nuclear power plants by CD solutions or CD polymers

2. Wastewater treatment:

- Sorption of toxic compounds by CD polymers [56-60],

- CD-assisted in situ oxidation (catalytic effect) - photodegradation of organophosphorus pesticides [61, 62], bisphenol [63];

- Improved biodegradation of xenobiotics by activated sludge - improved bioavailability of the contaminants reduced toxicity, use of cyclodextrin polymers as support for biofilms [64-66]

3. Contaminated soils treatment:

- Removal of organic and inorganic pollutants by soil washing with aqueous solutions of CD derivatives ("sugar flushing" or cyclodextrin-enhanced in situ flushing) - pentachlorophenol flushing [67], PAHs flushing [68], pesticide removal [69-72], different organic compounds and heavy metals removal [73, 74].

- Fig. 4 shows a conceptual illustration of the cyclodextrin-enhanced in situ flushing (CDEF) of contaminated porous media. The operation generally begins with the injection of a water-based cyclodextrin solution. There are two treatment options: using a system of designated injection and extraction wells to flush the source zone (see Figure 3) or injecting and extracting the flushing solution from one and the same wells, i.e., a push-pull operation. Because the magnitude of solubilization of organic contaminants is a linear function of the aqueous cyclodextrin concentration, the contaminant removal rate increases with the cyclodextrin concentration.

- Mineralization and detoxification of the organic and inorganic pollutants: mercury compounds [75];

- CD-assisted in situ oxidation (catalytic effect) - HPBCD-mediated iron-activated persulfate oxidation of trichloroethylene and tetrachloroethylene [76], photo-Fenton treatment of 2,4,6-trinitrotoluene contaminated soil after flushing with cyclodextrin [77], remediation of hexachlorobenzene in soil by enhanced Fenton process [78];

- CD-assisted electrokinetic remediation (improved mobility) - for 2,4-dinitrotoluene removal [79], for hexachlorobenzene removal [80], for phenanthrene removal [81], for a mixture of organic compounds and heavy metals removal [82]; 


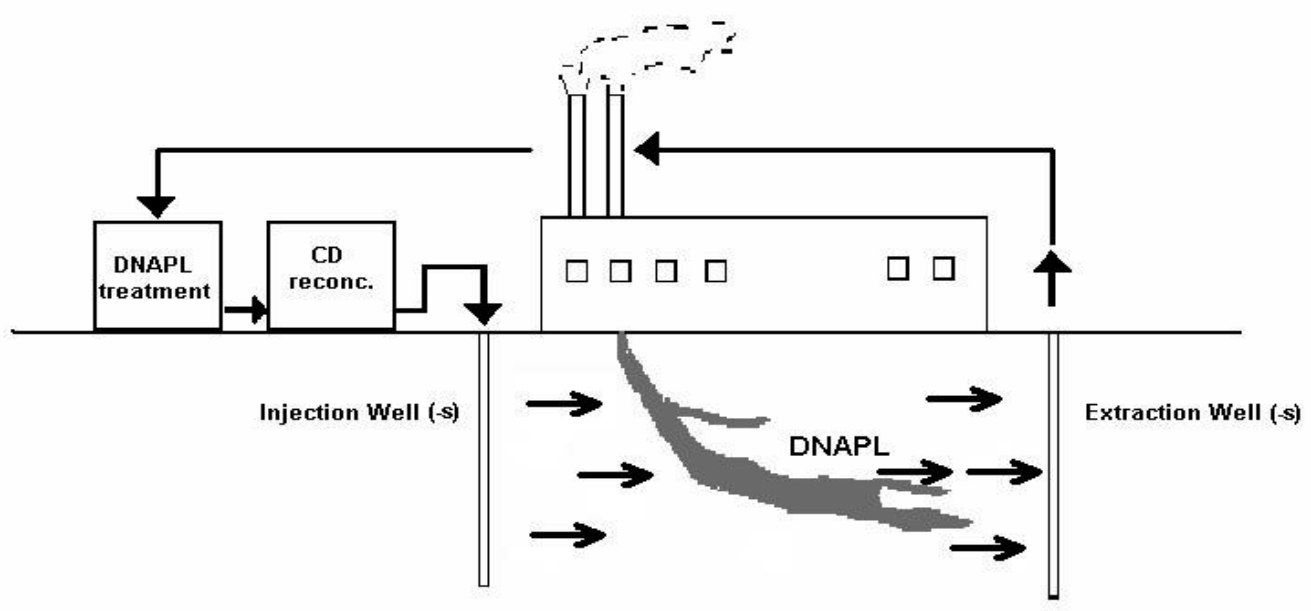

Fig. 4. Conceptual scheme of the CDEF technology (CD - cyclodextrin, DNALP - dense nonaqueous phase liquid).

- CD-assisted soil bioremediation (improved bioavailability of the contaminants, enhanced biomass production, reduced toxicity) - for phenols and PAHs [83], for 2-nitrobiphenil [84], for pyrene [85], for phenanthrene [86], fluorene [87], transformed oil [88];

- CD-assisted phytoremediation of PAHs contaminated soils [89], PCBs contaminated soils [90];

- CDs for assessment of bacterial degradability of PAHs and other pollutants in soils [91, 92]

4. Reduction of emission of wastes:

- Dose reduction of agrochemicals (insecticides, pesticides, fungicides) by complexation - for 10-undecyn-1-ol [93], for iprodine [94]

- CD-containing, biodegradable plastics $[95,96]$.

\section{Agriculture}

The main field of cyclodextrins' application in agriculture is pesticides complexation. Technological advantages that can be achieved applying cyclodextrins in pesticides production technologies are:

1. stable, standardized compositions;

2. improved wettability;

3. simple dosing and handling of dry powders;

4. reduced packing and storage costs;

5. more economical manufacturing processes

6. reduced labor costs.

Further are described the general advantages of pesticide-cyclodextrin complexes use with examples of such preparations (Fig. 3).

- improvement of the physicochemical characteristics of pesticides (disguised lipophilicity, improved wettability, decreased vapor pressure, enhanced aqueous solubility, etc.) - for chloramidophos [97], for thiabendazole (9), carbendazim (10) and fuberidazole (11) [98], for 3-chloro-p-toluidine (12) [99], for 2,4-dichlorphenoxyacetic acid (13) [100];

- $\quad$ enhancement of bioavailability of poorly soluble and absorbable pesticides - for imazalil (14) [101], for different fungicides [102];

- $\quad$ improvement of shelf-life (improved stability to heat, light, oxygen) - for chloramine phosphate [103];

- minimizing the container/content interaction in packaged formulations;

- $\quad$ improved homogeneity and content uniformity in finished product;

- reduction of the applied dose, minimizing environmental pollution.<smiles>COC(=O)Nc1nc2ccccc2[nH]1</smiles>

(9)<smiles>c1ccc2[nH]c(-c3cscn3)nc2c1</smiles>

(10)<smiles>c1coc(-c2nc3ccccc3[nH]2)c1</smiles>

(11) 
<smiles>Cc1ccc(N)c(Cl)c1</smiles>

(12)

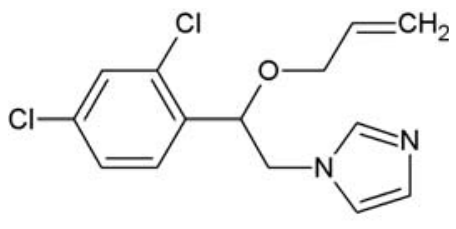

(13)

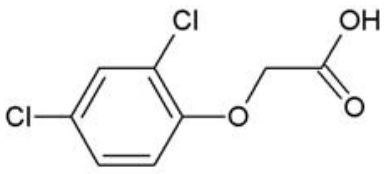

(14)

Fig. 5. Structures of some pesticides for which cyclodextrin complexes have been developed: thiabendazole (9), carbendazim (10), fuberidazole (11), 3-chloro-p-toluidine (12), 2,4-dichlorphenoxyacetic acid (13), imazalil (14)

Most of the above benefits can be attained by cyclodextrin complexation without chemical modification of the active substances. This means that no new chemical entities are introduced and just the known active compounds are developed in new, molecularly dispersed, stable, water-activated form. This saves time and money on registration process. Moreover, as enzyme-modified starch derivatives, cyclodextrins are considered non-toxic and from the environmental standpoint they are regarded as biodegradable carbohydrates.

\section{References}

[1] Szejtli, J. Pure Appl. Chem. 2004, 76(10), 1825-1845.

[2] Reineccius, T.A.; Reineccius, G.A.; Peppard, T.L. J. Food Sci. 2002, 67(9), 3271-3279.

[3] Szente, L.; Szejtli, J. J. Food Sci. 1986, 51(4), 1024-1027.

[4] Motoki, M. Japan Patent JP2005046028, 24.02.2005.

[5] Ishida, K.; Kunieda, S.; Amano, A. Japan Patent JP2002003430, 02.01.2002.

[6] Bhandari, B.R.; D’Arcy, B.R.; Padukka, I. J. Agric. Food Chem. 1999, 47(12), 5194-5197.

[7] Tanaka, T.; Okemoto, H.; Kuwahara, N. Japan Patent JP6248194, 26.08.1994.

[8] Lopez-Nicolas, J.M.; Garcia-Carmona, F. J. Agric. Food Chem. 2007, 55(15), 6330-6338.

[9] Lopez-Nicolas, J.M.; Perez-Lopez, A.J.; Carbonell-Barrachina, A.; Garcia-Carmona, F. J. Agric. Food Chem. 2007, 55(13), 5312-5319.

[10] Wimmer, T.; Regiert, M.; Moldenhauer, J.P. US Patent US6025510, 15.02.2000.

[11] Shaw, P.E.; Wilson, C.W. J. Food Sci. 1983, 48(2), 646-647.

[12] Shaw, P.E.; Wilson, C.W. J. Food Sci. 1985, 50(4), 1205-1207.

[13] Yonetani, T.; Tanikawa, A. Japan Patent JP11056243, 02.03.1999.

[14] Park, M.G. Korean Patent KR20040031672, 13.04.2004.

[15] Shinjiyou, K. Japan Patent JP57149238, 14.09.1982.

[16] Karl, C.L.; Schynoll, W.G. US Patent US4751095, 06.14.1988.

[17] Ontani, K.; Aikawa, Y.; Fujusawa, Y. et al. Chem. Pharm. Bull. 1991, 39(12), 3172-3174.

[18] Garbow, J.R.; Likos, J.J.; Schroeder, S.A. J. Agric. Food Chem. 2001, 49(4), 2053-2060.

[19] Lee, D.K.; Ahn, J.; Kwak, H.S. J. Dairy Sci. 1999, 82, 2327-2330.

[20] Ahn, J.; Kwak, H.S. J. Food Sci. 1999, 64(4), 629-632.

[21] Kwak, H.S.; Jung, C.S.; Shim, S.Y.; Ahn, J. J. Agric. Food Chem. 2002, 50(25), 7293-7298.

[22] Kim, J.J.; Jung, T.H.; Ahn, J.; Kwak, H.S. J. Dairy Sci. 2006, 89, 4502-4510.

[23] Cully, J.; Vollbrech, H.R. US Patent US005342633, 30.08.1994.

[24] Plank, D.; Lewandowski, D. US Patent US2004116382, 01.07.2004.

[25] Schmid, G.; Reuscher, H.; Antlsperger, G. US Patent US 20040161526, 19.08.2004.

[26] Terao, K.; Tate, I.; Nakada, D. Japan Patent JP2006008568, 12.01.2006.

[27] Zeller, B.L.; Kim, D.A. US Patent US2008069924, 27.03.2008.

[28] Woo, R.A.; Trinh, T.; Cobb, D.S. et al. US, World Patent WO9856889, 17.12.1998.

[29] Food Standards Australia-New Zealand. A438-Gamma-cyclodextrin as a novel food additive. 19.03.2003.

[30] Food Standards Australia-New Zealand. A494-Alfa-cyclodextrin as a novel food. 20.10.2004.

[31] Numanoğlu, U.; Şen, T.; Tarimici, N.; Kartal, M.; Koo, O.M.Y.; Önyüksel, H. AAPS PharmSciTech. 2007, 8(4), Article 85 (http://www.aapspharmscitech.org).

[32] Prosek, M.; Smidovnik, A. ; Fir, M. et al. Slovenia Patent SI21992, 31.10.2006.

[33] Fredon, L.; Orsoni, L.; Ferrandis, A.; Mallard, C. France Patent FR2879459, 22.12.2004.

[34] Denadai, A.M.; Teixeira, K.I.; Santoro, M.M. et al. Carbohydr. Res. 2007, 342(15), 2286-2296.

[35] Tsushima, Y.; Shirai, H.; Furuya, M. Japan, World Patent WO2008007425, 17.01.2008.

[36] Regiert, M.; Kupka, M. German Patent DE10253042, 03.06.2004.

[37] Shefer, A.; Shefer, S.D. US Patent US2003018988, 24.12.2003.

[38] Scalia, S.; Tursilli, R.; Iannuccelli, V. J. Pharm. Biomed. Anal. 2007, 44(1), 29-34. 
[39] Anselmi, C.; Centini, M.; Maggiore, M. et al. J. Pharm. Biomed. Anal. 2008, 46 (4), 645-652.

[40] Badin, F.E.; Ndou, T.T.; Lim, L.K.; Yin, Y.; Tzeng, M.M. US Patent US5653971, 29.03.1998.

[41] Yamashita, T.; Ohashi, Y. Japan Patent JP2008044904, 28.02.2008.

[42] Citernesi, U.; Sciacchitano, M. Cosmet. Toiletries. 1995, 110(3), 53-61.

[43] Saeki, T. Japan Patent JP11209784, 03.08.1999.

[44] Terauchi, T.; Narai, M. Japan Patent JP2001316219, 13.11.2001.

[45] Sumiyoshi, H.; Oishi, M. Japan Patent JP2001240892, 04.09.2001.

[46] Ogino, S.; Kamiya, H. Japan Patent JP63194726, 11.08.1988.

[47] Lucas, J.M.; Trinh, T.; Buckner, R.Y.; Kajs, T.M. US Patent US5858335, 12.01.1999.

[48] Tanaka, H.; Momose H. Japan Patent JP7196458, 01.08.1995.

[49] Felton, L.A.; Wiley, C.J.; Godwin, D.A. Drug Dev. Ind. Pharm. 2002, 28(9), 1117-1124.

[50] Simeoni, S.; Scalia, S.; Benson, H.A. Int. J. Pharm. 2004, 280(1-2), 163-171.

[51] Max, H.; Nilesen, J.; Raschke, T. US Patent US20020076389, 20.06.2002.

[52] Cassez, A.; Ponchel, A.; Bricout, H.; Fourmentin, S.; Landy, D.; Monflier, E. Catal. Lett. 2006, 108(3-4), 209214.

[53] Fourmentin, S.; Outirite, M.; Blach, P. et al. J. Hazard. Mater. 2007, 141(1), 92-97.

[54] Blach, P.; Fourmentin, S.; Landy, D.; Cazier, F.; Surpateanu, G. Chemosphere. 2008, 70(3), 374-380.

[55] Szente, L.; Fenyvesi, E.; Szejtli J. Environ. Sci. Technol. 1999, 33(24), 4495-4498.

[56] Kitaoka, M.; Hayashi, K. J. Incl. Phenom. Macro. 2002, 44(1-4), 429-431.

[57] Orprecio, R.; Evans, C.H. J. Appl. Polym. Sci. 2003, 90(8), 2103-2110.

[58] Crini, G. Prog. Polym. Sci. 2005, 30(1), 38-70.

[59] Crini, G. Bioresource Technol. 2003, 90(2), 193-198.

[60] Ozmen, E.Y.; Sezgin, M.; Yilmaz, A.; Yilmaz, M. Bioresour.Technol. 2008, 99(3), 526-531.

[61] Ishiwata, S.; Kamiya, M. Chemosphere. 1999, 39(10), 1595-1600.

[62] Kamiya, M.; Kameyama, K.; Ishiwata, S. Chemosphere. 2001, 42(3), 251-255.

[63] Wang, G.W. China Patent CN1778704, 2006.05.31.

[64] Buser, H.R.; Muller, M.D. Eviron. Sci. Technol. 1995, 29, 664-672.

[65] Furuta, T.; Ikefuji, S.; Tokunaga, K.; Neoh, T. L.; Yoshii H. J. Incl. Phenom. Macro. 2007, 57(1-4), 21-27.

[66] Sevillano, X.; Isasi, J.R.; Peñas, F.J. Biodegradation. 2008, 19(4), 589-597.

[67] Hanna, K.; Chiron, S.; Oturan, M.A. Water Res. 2005, 39(12), 2763-2773.

[68] Viglianti, C.; Hanna, K.; de Brauer, C.; Germain, P. Environ. Pollut. 2006, 140(3), 427-435.

[69] Morillo, E.; Perez-Martinez, J.I.; Gines, G.M. Chemosphere. 2001, 44(5), 1065-1069.

[70] Villaverde, J.; Maqueda, C.; Morillo, E. J. Agric. Food Chem. 2005, 53(13), 5366-5372.

[71] Villaverde, J. J. Hazard. Mater. 2007, 142(1-2), 184-190.

[72] Villaverde, J.; Maqueda, C.; Undabeytia, T.; Morillo, E. Chemosphere. 2007, 69(4), 575-584.

[73] Brusseau, M. L.; Wang, X.; Hu, Q. Environ. Sci. Technol. 1994, 28(5), 952-956.

[74] Brusseau, M.L.; Wang, X.; Wang, W. Environ. Sci. Technol. 1997, 31, 1087-1092.

[75] Cathum, S.; Velicogna, D.; Obenauf, A. et al. Anal. Bioanal. Chem. 2005, 381(8), 1491-1498.

[76] Liang, C. ; Huang, C.F.; Mohanty, N.; Lu, C.J.; Kurakalva, R.M. Ind. Eng. Chem. Res. 2007, 46(20), 6466-6479.

[77] Yardin, G.; Chiron, S. Chemosphere. 2006, 62(9),1395-1402.

[78] Oonnittan, A.; Shrestha, R.A.; Sillanpaa, M. J. Environ. Sci. Health. A Tox. Hazard. Subst. Environ. Eng. 2008, 43(8), 894-900.

[79] Khodadoust, A.P. ; Reddy, K.R.; Narla O. J. Envir. Engrg., 2006, 132(9), 1043-1050.

[80] Yuan, S.; Tian, M.; Lu, X. J. Hazard Mater. 2006, 137 (2), 1218-1225.

[81] Niqui-Arroyo, J.L.; Bueno-Montes, M.; Posada-Baquero, R.; Ortega-Calvo, J.J. Environ. Pollut. 2006, 142(2), 326332.

[82] Maturi, K.; Reddy, K.R. Chemosphere. 2006, 63(6), 1022-1031.

[83] Allan, I.J.; Semple, K.T.; Hare, R.; Reid, B.J. Environ. Sci. Technol. 2007, 41(15), 5498-5504.

[84] Cai, B.C.; Gao, S.X.; Lu, G.F. J. Environ. Sci (China). 2006, 18(6), 1157-1160.

[85] Wang, J.M.; Maier, R.M.; Brusseau, M.L. Chemosphere. 2005, 60(5), 725-728.

[86] Reid, B.J.; Stokes, J.D.; Jones, K.C.; Semple, K.T. Environ. Toxicol. Chem. 2004, 23(3), 550-556.

[87] Garon, D.; Sage, L.; Wouessidgewe, D.; Seigle-Murandi, F. Chemosphere. 2004, 56(2), 159-166.

[88] Molnar, M.; Leitgib, L.; Gruiz, K. et al. Biodegradation. 2005, 16(2), 159-168.

[89] Bardi, L.; Martini, C.; Opsi, F. et al. J. Incl. Phenom. Macro. 2007, 54(1-4), 439-444.

[90] Mackova, M.; Barriault, D.; Francova, K. et al. Phytoremediation of Polychlorinated Biphenyls. Book: Phytoremediation Rhizoremediation. Springer: Netherlans, 2006; pp 143-167.

[91] Stokes, J.D.; Wilkinson, A.; Reid, B.J.; Jones, K.C.; Semple, K.T. Environ. Toxicol. Chem. 2005, 24(6), 13251330. 
[92] Oleszczuk, P. J. Environ. Sci. Health. A Tox. Hazard. Subst. Environ. Eng. 2008, 43(1), 10-17.

[93] Neoh, T.L.; Tanimoto, T.; Ikefuji, S.; Yoshii, H.; Furuta, T. J. Agric. Food Chem. 2008, 56(10), 3699-3705.

[94] Zhu, X.L.; Wang, H.B.; Chen, Q.; Yang, W.C.; Yang, G.F. J. Agric. Food Chem. 2007, 55(9), 3535-3539.

[95] Shuai, X.; Wei, M.; Porbeni, F.I.; Bullions, T.A.; Tonelli, A.E. Biomacromolecules. 2002, 3(1), 201-207.

[96] Rusa, C.C.; Shuai, X.; Shin, I.D. et al. J. Polym. Environ. 2004, 12(3), 157-163.

[97] Zhou, S.; Wang, L.; Zhang, A.; Lin, K.; Liu, W. J. Agric. Food Chem. 2008, 56(8), 2708-2713.

[98] Lezcano, M. ; Al-Soufi, W. ; Novo, M. ; Rodriguez-Nunez, E. ; Tato, J.V. J. Agric. Food Chem. 2002, 50(1), 108-112.

[99] Hurley, J.C.; Volz, S.A.; Johnston, J.J. J. Agric. Food Chem. 1999, 47(7), 2904-2907.

[100] Pérez-Martínez, J.I.; Ginés, J.M.; Morillo, E. et al. Pest Manag. Sci. 2000, 56(5), 425-430.

[101] Schirra, M.; Delogu, G.; Cabras, P. et al. J. Agric. Food Chem. 2002, 50(23), 6790-6797.

[102] Szejtli, J.; Kiniczky, M.; Tetenyi, P. et al. European Patent EP0208757, 21.01.1987.

[103] Zhou, L.W. China Patent CN101019531, 22.08.2007. 